\title{
INSPECTORATE SUPERVISION IN APPLYING COMPETITIVE PRINCIPLES IN MANAGING PROCUREMENT OF GOODS / SERVICES IN GOVERNMENT OF NORTH SULAWESI PROVINCE
}

\author{
Novrabella Clarashinta Pakasi ${ }^{1}$ \\ ${ }^{1}$ Regional Inspectorate of North Sulawesi Province, Manado, 95119, Indonesia \\ Corresponding e-mail : kemper_pakasi@yahoo.com
}

\begin{abstract}
This paper examines the supervision of the Inspectorate on the application of the principle of competitiveness in the management of government goods/services procurement. This research was conducted at the North Sulawesi Provincial Government. The essence of this paper aims to find out whether the Inspectorate has supervised the application of the principle of competitiveness in the management of procurement of goods/services to the North Sulawesi Provincial Government. The methodology used in this study is qualitative. The techniques and procedures for collecting data through in-depth interviews with a number of informants related to the application of the principle of competitiveness in the management of procurement of goods/services. Activities in the analysis include data reduction, data display, and conclusion drawing/verification. The results of this study indicate that the Inspectorate has been maximal enough to carry out supervision of the application of the principle of competitiveness in the procurement of goods/services in North Sulawesi Province.
\end{abstract}

Keywords : Inspectorate, Competing, Management, Goods/Services

JEL Classification : H10, H11

Article info:

Received 1 December 2018

Revised 15 December 2018

Accepted 20 December 2018

Available online 31 December 2018

\section{INTRODUCTION}

Factors that become indicators of the success of a development process are determined by the implementation of the procurement of goods and services. The reason is that in every implementation of development in all sectors generally requires the procurement of goods and services. To ensure the success of the management of procurement of goods and services, it is very important to supervise the government internal control apparatus (APIP) and human resources who carry out the management of procurement of goods and services. With the supervision of APIP as well as human resources for the procurement of good quality government goods and services, fraud in the procurement of government goods and services will not occur.

In relation to the functions of the Provincial, Regency/City Inspectorate generally regulated in the Minister of Home Affairs Regulation Number 64 of 2007 article 4, states that in carrying out the task of overseeing government affairs, the Provincial, Regency/City Inspectorates have the following functions: planning of supervision programs; second, formulation of supervision policies and facilities; and third, examination, investigation, testing and assessment of supervisory duties and one of its authorities in the field of supervision is procurement. In connection with that, the role of the Inspectorate is needed to 
narrow the space for the perpetrators, especially those who want to commit fraud in the procurement of goods / services for their personal interests.

The fact that is currently encountered, even though the supervision has been carried out by APIP from the Inspectorate, but still encountered problems in the process of procurement of government goods and services. The problems that most often occur in the process of procurement of goods and services are related to dishonesty in the form of collusion, nepotism and even corruption $(\mathrm{KKN})$. To prevent various irregularities in the procurement process of government goods and services, there are principles for the procurement of goods and services that are used as guidelines for parties involved in this process as stated in the Republic of Indonesia Presidential Regulation Number 54 of 2010 concerning Procurement of Goods / Services Government. The following principles are efficient, namely procurement is carried out to achieve the results determined by the use of minimal, effective resources, namely the results in accordance with the targets planned and in accordance with needs, transparent, namely clear and accessible rules for all parties, namely procurement can followed by all participants who meet the requirements, competing, namely fair competition without intervention, fair / non-discriminatory, namely equal treatment of all participants and not towards certain participants and accountable, namely compliance with procurement procedures. With the existence of these principles, the perpetrators of government goods and services procurement have clear boundaries on how to carry out their duties and functions in accordance with applicable regulations.

Hardi (2016: 2) presents various problems regarding the procurement of government goods / services that are not transparent, not accountable, not responsibility, not independent, and unfair. This can be seen at each stage, starting with the planning stage, which is specifying the specific product, the HPS value is inflated, setting the provider conditions that are directed to certain providers, arranging the schedule too fast, so that the prepared provider submits the offer, restrictions on information, so that only certain providers get complete information. In the selection phase which becomes a problem, namely announcement of the auction (pseudo or fictitious, incomplete content, short announcement time), the working group does not master the technical substance and important information which will be explained in aanwijzing, does not make arithmetic corrections for unit price contracts, does not carry out clarity in evaluation process. In the contract implementation phase, the problem is the submission of the main work to another company / sub-contractor, the supervisor or inspector of the work to make an incorrect report or falsify the report to cover the wrong conditions, the payment exceeds the progress. In the handover phase which becomes a problem, the physical work has not been completed $100 \%$, the quality of goods / services does not meet the standards and specifications stated in the contract.

By many problems that occur in the practice of procurement of goods and services causes a lack of public confidence in the APIP Inspectorate which supervises the management of procurement of goods/services of the government as well as the managers of goods / services in the regional apparatus. As O'Regan (2012) stated that the public does not trust the public sector procurement process and also the Auditor General report (2008) shows that the public sector procurement process is not possible to enable the achievement of constitutional procurement objectives. Based on the description above, the authors are interested in examining the supervision of the Inspectorate on the application of the principle of competitiveness in the management of government goods/services procurement. The North Sulawesi Provincial Government was chosen as the location of the study because it was based on the human development index (World Heritage Encyclopedia, 2008: 1), North Sulawesi Province was one of the provinces categorized as high human development, where the value of North Sulawesi Province was 0.758, ranked second after Jakarta Special Capital Region with a value of 0.808. In 2015, based on the List of Indonesian Provinces By the Human 
Development Index (Wikipedia, 2015), North Sulawesi still had a "high" status with a value of 0.704. It must be seen that the human resources of North Sulawesi Province are categorized as superior. In addition, North Sulawesi Province is one of the provinces that is experiencing very rapid development, can be seen from the results of development. The results of the development are a manifestation of the efforts of the North Sulawesi Provincial Government to further improve public services for its people. To be able to succeed in the development program, the North Sulawesi Provincial Government issued a budget that was not small, especially regarding the procurement of government goods/services.

If seen from the giving of opinion from the Supreme Audit Agency (BPK) of the Republic of Indonesia of North Sulawesi, indeed the North Sulawesi Provincial Government is still facing problems especially in the government goods / services procurement sector. This can be seen in the 2013 report on the supervision of state financial accountability in North Sulawesi. The BPK provided fair opinions with the exception of the North Sulawesi Provincial Government balance sheet as of December 31, 2013. WTP opinion from the BPK has not been obtained due to weaknesses in the internal control system. regional property in an orderly manner, inadequate implementation of the procurement of goods and services with applicable provisions, presentation of financial statements that are not yet in accordance with government accounting standards (SAP), weaknesses in the financial report preparation system, and inadequate competency of financial management HR in local governments. Indeed, the BPK has provided an unqualified opinion on North Sulawesi Provincial LKPD 2014 Budget Year, but this does not mean that the North Sulawesi Provincial Government has been free of findings. Even though I have obtained a WTP opinion but there are still 31 findings. A total of 12 findings are weaknesses in the design and implementation of the internal control system, and 19 findings related to compliance with legislation. The purpose of the study was to determine whether the Inspectorate had been maximized in supervising the application of the principle of competitiveness in the management of Goods/ Services Procurement at the North Sulawesi Provincial Government.

\section{LITERATURE REVIEWS}

2.1. Supervision of the Inspectorate

The essence of supervision is to prevent as early as possible the occurrence of irregularities, waste, abuse, obstacles, mistakes, failure in achieving goals and implementation of organizational tasks. Supervision is the process of observation from the implementation of all organizational activities to ensure that all work carried out goes according to a predetermined plan (Rheza, 2011). Yulika (2015) explained the role of the Inspectorate in overseeing the procurement of goods / services, namely:

1. Planning Phase: to provide confidence that the budget for PBJ has been accommodated and has a clear legal basis.

2. Implementation Preparation Phase: to provide advice and input in meetings to prepare for work, provide advice on the implementation of work, especially handling delays in the implementation of work, provide advice and solutions to jobs that have the potential to break contracts or contracts that are extended or extended time past the budget year. Participated in publishing Perwako No. 59 Years of Extension of Time that passes the fiscal year.

3. Procurement Process Phase: to carry out checks and provide answers / suggestions for complaints or objections to the process of procurement of goods and services delivered by construction service providers or the public, take firm action against contracts that are terminated due to their own negligence (wan achievement) by issuing recommendation letters the implementation of a black list against companies with achievements due to negligence of contractors. 


\section{2. $\quad$ Procurement of Government Goods and Services}

Tanesia (2015) explains that the procurement of goods and services is carried out by government agencies and the private sector. This activity is carried out to obtain goods and services for an agency / institution whose process starts from planning needs to completion of all activities to obtain the goods and services. Procurement of goods and services ideally aims to ensure efficiency, transparency and fairness in the implementation of development activities by the government (Listiyanto, 2012). Procurement of goods and services in an agency or company is a routine activity that is always carried out. Procurement of goods and services is intended to meet the needs of goods and services for the operational continuity of agencies or companies (Heryandi et al., 2015). In principle, procurement is an activity to obtain goods, or services in a transparent, effective and efficient manner according to the needs and desires of its users, which means goods here include equipment and buildings for both public and private interests (Anonymous, 2011a).

\subsection{Management of Procurement of Goods and Services}

Management comes from the word management, in a large contemporary Indonesian dictionary written by Salim and Salim (2002) means to lead, control, regulate, and strive for better, more advanced and so on and be responsible for certain jobs. Management is a process that helps formulate policies and objectives providing oversight of all things involved in the implementation and achievement of goals. The management cycle of procurement of goods/services through goods/services providers as founded by Arsana (2016) which are planning, implementation and control.

\subsection{Principles of Procurement of Goods and Services That Are Competitive}

The basic principles of government procurement of goods/services are efficient, effective, open and competitive, transparent, fair / non-discriminatory, and accountable (Lubis, 2014: 6-9) and (Willem, 2012: 11-12). Competition comes from English, namely competition which means competition itself or competing activities, competitions, competitions (Maribun, 2003). Competing is the real condition faced by everyone in the present. Competition and competition if faced positively or negatively, depends on our attitude and mental perception in interpreting the competition. Almost nothing without competition / competition, as well as competition in achievement, the business world even in the learning process. Competition is a kind of effort to support a higher position in the business world. If the number of competitors is quite large and balanced, competition will be very high because each company has relatively the same resources. If the number of competitors is the same but there are differences in resources, then it will be seen which one will be the market leader, and which company is the follower. The principle of open and competitive means that the procurement of goods / services must be open to providers of goods/services that meet the requirements and carried out through fair competition among providers of goods/services that are equal and meet certain requirements / criteria based on clear and transparent provisions and procedures. In Presidential Regulation No. 54 of 2010 as amended by Presidential Regulation No. 4 of 2016, what is meant by competing means that the procurement of goods/services must be carried out through fair competition among as many as possible providers of goods/services that are equal and fulfill requirements, so that competitive goods/services can be obtained and no interventions that interfere with the creation of market mechanisms in the procurement of goods/services. It can be concluded that what is meant by the principle of fair competition in the procurement of goods and services is the competition between prospective providers of goods and services based on applicable ethics and procurement norms, there is no fraud and KKN practices. 


\section{RESEARCH METHODS}

\subsection{Research informant}

Saroinsong et al (2012) research with a descriptive approach to determining the number of respondents there is no absolute measure. Informants are chosen with the aim of describing a social phenomenon or a particular social problem based on certain considerations so that it is called sampling purpose (purposive sampling). Informants in this study are Commitment Making Officials (PPK), Activity Technical Executing Officers (PPTK), Procurement Officials, Workers Receiving Committees/Officers, third parties at the Public Works Agency, Health Service, National Education Service, Culture and Tourism Service and the Development Bureau of the Regional Secretariat of North Sulawesi Province, POKJA Procurement Services Unit and Auditors from the Inspectorate of North Sulawesi Province were taken.

\subsection{Research focus}

The focus of research is the supervision of the Inspectorate on the application of the principle of competitiveness in the management of government goods/services procurement. Where the Inspectorate oversees whether the regional apparatus has applied the principle of competitiveness, that is carried out through fair competition among providers of goods and services that are equal and fulfills certain conditions/criteria based on clear and transparent provisions and procedures with descriptions: conditions that enable each prospective participant able to conduct self-evaluation related to its competitive level and the opportunity to win the competition; in each stage of the procurement process must encourage healthy competition; the manager of the procurement of goods and services must actively eliminate matters that hinder the occurrence of fair competition; avoid conflict of interest; and the principle of non-discrimination is strictly enforced.

\subsection{Method of analysis}

Miles and Huberman (1984) (in Sugiyono, 2008), suggest that activities in qualitative data analysis are carried out interactively and take place continuously until complete, so the data is saturated. The size of data saturation is indicated by no new data or information obtained. Activities in the analysis include data reduction, presenting data, and drawing conclusions and verification.

\section{RESULTS AND DISCUSSIONS}

\subsection{Results}

It can be explained based on the results of in-depth interviews regarding the supervision of the Inspectorate on the application of the principle of competitiveness in the management of government goods/services procurement, that currently the regional Inspectorate is quite maximal in overseeing the application of competing principles in the management of goods/ services procurement in the North Sulawesi provincial government but for procurement management goods/services in the regional apparatus in the government of North Sulawesi Province have not fully implemented the competitive principle.

To be able to answer the research question, a proposition was made, namely with the supervision of the Inspectorate on the application of the principle of competitiveness in the management of government goods/services procurement, it would increase the effectiveness of the procurement of goods and services, especially in the North Sulawesi provincial government. The following are the results of interviews with informants regarding supervision from the Inspectorate on the application of the principle of competitiveness in the management of government goods/services procurement.

"For supervision of the management of procurement of goods and services in regional equipment, the Inspectorate is quite maximal. This is seen from the supervision carried out by APIP at the Inspectorate. These controls include the probity audit where the probity audit is 
an assessment activity to ensure that the process of procurement of goods / services carried out on regional equipment has been carried out consistently and has been in accordance with the principles of integrity, truth and honesty and complies with applicable regulations. which aims to increase accountability for the use of public sector funds. In addition to Probity audit, an audit of financial management is also conducted, in this examination it includes the procurement of goods and services. In the supervision carried out by the APIP inspectorate, it also assessed whether the management of procurement was in accordance with the principle of competition.

Authors: have regional apparatus already implemented competing principles in the management of goods and services procurement?

So far not yet. Why do I say no, especially for procurement with a value of under 200 million or direct appointment, not all parties should have the opportunity to participate in the direct appointment of procurement packages, not all have access to compete with providers which have indeed become "permanent operations" procurement in regional equipment?

Author: Is there no real action from APIP to prevent this?

Certainly, there are certain actions, one of which is by providing suggestions for improvements where the regional apparatus is required to submit all procurement packages in accordance with the provisions, so that the information can reach all parties. But indeed, we realize that this is not yet possible, because there are obstacles such as budgets that do not allow announcements in all media determined according to applicable rules

Author: Can APIP not directly supervise when the procurement packages are appointed? Constraints on the part of the Examining Team: to carry out the inspection, the auditors have already had a schedule of checks called the Annual Oversight Work Program, where all PKPT audits are scheduled, both day and month and also the SKPDs to be examined, this is which causes why auditors cannot fully supervise at every stage of the government procurement of goods /services. The constraints on the SKPD, namely the schedule for the procurement of goods/services at the SKPD sometimes changes not according to planning, this is what causes the inspection team from the inspectorate to sometimes not be able to carry out audits at certain stages. (Auditor).

The APIP Inspectorate can be said to be quite maximal in the implementation of supervision over the management of goods / services procurement in the regional apparatus, which is a problem that is not all what is suggested by APIP is followed up by regional officials. Specifically concerning the principle of competing in procurement management, APIP in the implementation of the examination has examined from the planning, implementation to supervision stages, where in the examination phase interviews were conducted with the procurement manager in the regional apparatus. not yet fully implemented. In addition to budget problems, also the issue of trust in the regional apparatus to implementers. Sometimes regional operators appoint new implementers to procure goods and services, but they are unable to show maximum performance, in contrast to implementers who have long worked with regional officials. This is what causes sometimes the principle of competing, especially jobs under 200 million, is difficult to implement. In contrast to the jobs that are auctioned, it generally does apply the principle of competitiveness. The results of further research to see whether the management of procurement of goods and services competitively has been applied to the government of North Sulawesi Province, the propositions will be drawn. First, the lack of independence of the officials managing the procurement of goods and services in the SKPD has resulted in corruption, collusion and 
nepotism in the procurement process. The second proposition is that the implementation of price negotiation procedures in the procurement of goods and services can prevent the price of goods and services from being overpriced. The third proposition, namely the implementation of the procurement of goods and services according to the implementation schedule, reduces the risk of collusion and nepotism. The following will explain each of the propositions.

Un-independent of the apparatus managing the procurement of goods and services in the Regional Apparatus resulting in corruption, collusion and nepotism in the procurement process. According to Mokoginta (2013: 1), being a manager of procurement of goods/services (officials/procurement committees/ULP working groups, commitment-making officials, officials/ recipients of work) is not a pleasant thing for some PNS. A lot of complaining and joy and sorrow when a civil servant is in charge of managing goods / services procurement. Starting from honorariums that are not proportional to the amount of work burden and risk up to the strong flow of intervention from certain parties. Intervention must be balanced with integrity. Integrity can be interpreted as an action that is in accordance with the norms, values, and principles that have been arranged. Integrity also means honesty. In the procurement of goods/services integrity is the first requirement that must be owned by commitment maker (PPK), ULP officials / procurement committees/working groups, and officials / recipients of work results (PPHP). The manifestation of integrity is stated in the integrity pact that must be signed by the PPK, ULP officials / procurement committees/working groups, and PPHP. A person's integrity is often shaky due to the intervention of certain parties. The form of intervention that often occurs in the process of procurement of goods/ services is the presence of orders or pressure to win certain providers. The term commonly used is "direction/deposit" which is wrapped in the word "policy". All parties involved seemed forced to secure the policy. Fighting policies can be considered as an act of disloyalty. As a result, a civil servant can be transferred (mutated) and even released (non-job). Loyalty is often misinterpreted as the attitude of someone who must submit to and follow whatever the boss orders, including crashing rules. Orders that are not in accordance with the Laws and Regulations must not be followed. Only people with integrity have the courage to "fight" this wrong policy. That is one reason why integrity is the first requirement that must be met by the management of goods / services procurement. Integrity is one of the main factors that can deny intervention. In general, interventions will adversely affect good governance and clean government. In the procurement of goods /services, interventions will disrupt the creation of market mechanisms and business competition which in turn will cause business competition to become unhealthy. Law Number 5 Year 1999 concerning the prohibition of monopolistic practices and unfair business competition defines unfair business competition as competition between business actors in carrying out production activities and or marketing of goods and or services carried out in a dishonest manner or against the law or inhibiting competition business. The Law also emphasizes that everyone who seeks in Indonesia must be in a situation of fair and fair competition, so that it does not create a concentration of economic power on certain business actors. Economic democracy requires equal opportunities for every citizen to participate in the process of production and marketing of goods and or services, in a healthy, effective and efficient business climate so as to encourage economic growth and the operation of a fair market economy. Interventions in the process of procurement of goods / services are not only at the stage of provider / tender selection. From upstream to downstream it seems as if it has never escaped intervention. Starting from the planning stage to the goods / services that exist (Mokoginta, 2013: 1). Planning stage; planning must be based on need (based on need) not solely on desire (based on want). Interventions often cause the budgeting process often based solely on the wishes of 
certain parties. Identification of needs that should be the basis of the preparation of activities becomes neglected. Stage of provider selection (tender); at this stage the flow of intervention is very strong. The process of selecting providers is often considered a formality. The actual winner of the tender has been around since the beginning. All procedures carried out are only attempts to abort the obligation. ULP committee / working group "forced" to turn the brain to win "deposit / direction" by all means. Arrangements in the process of selecting the Provider are carried out. The indication of the arrangement is actually easy to recognize. Some examples of indications of regulation in the process of selecting providers include deliberate auctions not done electronically (electronic tendering); the requirements in the selection document are not in accordance with the provisions and fabricate with the aim of narrowing down the opportunities of other providers; at the auction electronically, the Provider has difficulty uploading the offer document. There are indications of being deliberately blocked through the system, so that only certain providers can upload bid documents; The provider won tends to have an offer value close to the value of the HPS (self-estimated price) with a rating below; and many other indications. Contract implementation phase; after the announcement of the winner and no objection / rebuttal is not correct, then the PPK issues SPPBJ (letter of appointment of the supplier of goods/ services). SPPBJ is the first step towards the Contract. PPK may not agree with the ULP committee / working group's decision in terms of determining the winner. A smart PPK should first examine all the processes carried out by the ULP committee / working group before issuing the SPPBJ. If someone does not comply with the provisions / violates the procedure, the PPK has the authority not to issue the SPPBJ. Furthermore, these problems are brought to the PA / KPA level to be decided. The PA / KPA decision is final. Interventions make KDP unable to do much even though they actually know something is wrong. The authority of KDP seems to be castrated. PPK is not active in carrying out its duties and its authority controls the implementation of contracts. In fact, on the contrary, often providers or other parties control the implementation of the Contract. The contract which ended with the handover of the work also did not escape the intervention. The handover report (BAST) of the work must be signed by PPHP even though the results are not in accordance with the provisions stipulated in the contract. The apparatus managing the procurement of goods and services in the regional apparatus of the North Sulawesi Provincial Government will be able to carry out their duties optimally if they do not get interventions to carry out other tasks that are not in accordance with the existing rules, but the results of this research still show intervention - intervention to the apparatus managing the procurement of goods and services in the regional apparatus. The following excerpts of the results of the interview concern the independence of the apparatus / service procurement apparatus. Informants who are commitment-making officials in the regional apparatus provide answers to the author's question regarding whether in the implementation of the task, have PPK (commitment-making officials) been intervened by certain parties. The following are the answers from the informants.

"You have to be loyal to your boss, so sometimes there is intervention. But experience in the field does not always have intervention from leaders or parties that have power" (PPK 1).

"Indeed, sometimes there are instructions from superiors, to say the language intervention sounds too harsh, maybe more direct instructions from superiors ... ...... (PPK 2).

A similar answer was also expressed by an informant who had a position as a technical executor in the regional apparatus. In general, informants have received intervention from the leadership. The following are the results of interviews with informants.

"Yes ........ Sometimes the leadership intervention in the form of who will be the winner of the procurement sometimes also speeds up payments even though we know (know) with the payment work not in accordance with the existing realization" (PPTK 1). 
"Ever......... It is usually about who will be appointed to be the executor of work "(PPTK 3). ".......... torang (we) are subordinate to the main postal employee who is loyal to the boss (working always is loyal to the boss), if you are loyal, you will be displaced (if you are disloyal, you will be displaced) procurement "(PPTK 4).

The procurement official is one of the personnel who plays an important role in the management of procurement of goods and services with procurement value under two queen million rupiah. By looking at the importance of the position of procurement officials, many procurement officials in the regional apparatus felt that there was leadership intervention in their work. The following are the results of interviews with procurement officials.

"Intervention to procurement officials is now a matter of course, I think procurement officials in all SKPD are certain in determining prospective suppliers of goods and services based on the leader's instructions" (Procurement Officer 1).

"Ever ... ... ... usually the prospective winner and procurement price" (Procurement Officer 2).

"Never ... ...... Usually in the management of procurement, both the winner and when the work is done" (Procurement Officer 4).

Like procurement officials, the working group (POKJA) also does not escape the interventions of certain parties when they carry out their duties. The following are the results of interviews with work groups.

"Ever.

Writer: who intervenes?

Leaders, SKPD heads sometimes have prospective providers on behalf of the leadership.

Author: What are you usually intervening in?

In terms of determining the job winner, the value of arithmetic correction and other matters "(LWG 1).

"Yes, I have, but not often ... ... ... In carrying out my duties as POKJA ULP" (POKJA 2).

The same question was also asked of the official who received the work, namely whether he had been intervened by certain parties. The following are the answers from the informants. From the results of this study it is clear that there are still interventions from superiors to managers of procurement of goods and services specifically to determine which companies will be the winners of procurement, of course this can be imposed in the collusion category in the procurement of goods and services. As a result of collusion in determining the winner of the procurement of goods and services, it will certainly have an impact on the implementation of the procurement of goods and services as well as the quality of the procurement of goods and services. With a company that turns out not to be a winner but becomes a winner because of the practice of collusion with officials managing goods and services, sometimes the results of the company's work are not optimal, unlike companies that are winners because of their efforts, companies like this sometimes show more serious performance, because they do not have a connection, so they are more afraid of making mistakes or cheating. In order to further clarify whether the management of procurement of goods and services in the government of North Sulawesi Province has applied the principle of competitiveness. Proposition 2 is the implementation of price negotiation procedures in the procurement of goods and services that can prevent the occurrence of the price of procurement of goods and services. The following is an explanation of the second proposition.

The implementation of price negotiation procedures in the procurement of goods and services can prevent the price of goods and services from being overpriced. Negotiations appear as an initial step before the contract is implemented, negotiation as a 
process for negotiating or which arises/ occurs before the parties agree. Negotiation is an activity and / means for the parties to hold talks / negotiations, where one party gives an offer to the other party and vice versa about something that is a common goal is expected to later reach an agreement. The agreement is expected to be reached as the meeting point of both parties because previously there were differences of opinion regarding something that was motivated by the existence of the same interest in question is the purpose of cooperation (Irianto, 2014: 66). Negotiations are carried out not only to reach agreement on the price and technical quality of goods/services but to obtain prices that are in accordance with the prevailing market prices and technically accountable. The main material that is the object of negotiation is the price and technical quality of goods and services. In terms of price, of course, the higher the agreed price, the greater the profit the provider will get. In terms of the quality of goods and services, the higher the quality of goods and services, the harder it is to do it and the more it requires costs to realize the goods. Therefore, providers of goods and services want high prices and / or low quality of goods and services. On the contrary, for the government as the budget owner and user of goods and services, of course, they want low prices and/or high-quality goods and services. Negotiations were carried out by the ULP working group and the procurement unit. Procurement represents the government with the leader of the company providing goods/ services that have been selected (through a selection process or through a direct appointment process) which will be appointed as the provider of goods/services. In the negotiation process of ULP working groups/procurement officials and leaders of goods/service providers companies have the same position and each party has the freedom to accept or reject the wishes of the other party. The agreed decision as a result of the negotiations will be stated in the minutes of negotiations which will be followed up with the contract signing. Therefore, negotiations must be carried out in good faith in order to realize the accountability of the process of procurement of government goods and services. In this study, it is clearly illustrated that specifically for procurement under Rp. 200,000,000, the implementation of price negotiations is sometimes only done in formality, even when it is not done, the minutes of the negotiation of prices stated in the work order / contract documents are only formalities for the purposes of file completeness. This is because the company that will be appointed as the winner is only the company that is obliged to enter the bid file, so that the negotiation has not been done to find the best offer, but only made a formality. The following are excerpts of the results of interviews with informants how the treatment of participants in the process of procurement of goods and services is in the stage of negotiating prices in the direct procurement process (procurement under $\mathrm{Rp}$. 200,000,000.00). Commitment officials in the informant regional apparatus give the following answers.

".......... For price negotiations, frankly if procurement is under 200 million, negotiations on prices have not been implemented ......... (PPK 1).

"......... As far as I know, negotiating prices is usually only spoken orally "(PPK 2).

".......... done together with procurement officials ... ... ... For the mechanism, we invite prospective providers who will be winners, and notify the procurement price.

Authors: were the minutes of the minutes, attendance lists and minutes of the event made during the meeting?

Usually not yet, later it will be made all by contract "(PPK 3).

The informant then gave an answer regarding the implementation of price negotiations, namely informants who held positions as procurement officials. The following are the details of the interview.

"......... For price negotiations it is not done, usually only on paper" (Procurement Officer 1). 
"If you treat the participants the same. For the negotiation mechanism, it is usually only verbal negotiations, but sometimes it is not done (Procurement Officer 2).

".......... For price negotiations, only be done verbally ...........It was made in conjunction with the contract being made, as a complete document" (Procurement Officer 3).

"Treat it the same. Price negotiations are carried out before work starts, and bargaining is done to get the net value that will be used as the contract value "(Procurement Officer 4).

The same question was also asked to the LWG. The question is how to treat the participants in the process of procurement of goods and services in the stages of negotiating prices in the direct procurement process (procurement under Rp. 200,000,000.00). The answers from the informants are explained below.

"Price negotiations are carried out verbally/face to face.

Providers submit bid prices. Procurement officials propose lower prices by calculating providers, but still take into account that they still get profits "(Working Group 1).

"Actually, for this matter, the procurement officials know better, the price negotiations are not carried out, except for only two companies that enter the bidding, we negotiate prices. However, according to my experience in SKPD, negotiations are generally carried out verbally, later on the news will be made following the signing of the contract or the management of disbursement of work "(Working Group 2).

The executor of the procurement of goods and services in the regional apparatus which is the research informant gives the answer regarding the implementation of negotiations on the procurement of goods and services in the regional apparatus. The following are answers from the informants.

"......... Usually only oral negotiations (usually only verbally negotiating), they are the price case (they give the price), yes, the default is no number (so they bargain with each other). ......... There is an official report, the regular march will be later (but usually later made) together with the complete payment documents" (Implementer 1).

"......... In the history we can (get) the project, you have ever had (never been there) price negotiation, this price negotiation is only on paper, so that (that) the complete files are in accordance with the applicable provisions "(Implementer 2).

"......... the negotiation stage is also just (only) a formality, because the price has been determined which is negotiated, usually how much is the contribution to SKPD ......... Author: what do you know the contribution is used for? What I know for policy "(Implementer 3).

"......... Price negotiations for procurement of under 200 million are only done formality. Price negotiations are only used as a complete file on procurement documents for the purpose of disbursing funds "(Implementer 4).

Price negotiations are sometimes only done formally. With the implementation of price negotiations that are only formality, of course, it can cause the procurement of goods and services implemented not to fully apply the principle of value for money, where regional apparatus with proper negotiation should be able to obtain goods and services with maximum quality, but due to the implementation of price negotiations which is not done, or done not optimally, so that the procurement of goods and services is sometimes done by issuing large funds but the quality of procurement is not in accordance with the funds issued. In order to further clarify whether the management of procurement of goods and services in the government of North Sulawesi Province has implemented the principle of alienation, the following follows the discussion of the proposition. Proposition 3, namely the implementation of procurement of goods and services according to the implementation 
schedule reduces the risk of collusion and nepotism. The following is an explanation of the description of the proposition.

The implementation of the procurement of goods and services according to the implementation schedule reduces the risk of collusion and nepotism. In planning the procurement of goods and services in the regional equipment contained in the procurement general plan (RUP), it is often found that the implementation time is not filled or filled only by determining between so many months to months, this certainly creates uncertainty both for the procurement manager. and services in regional equipment and prospective suppliers of goods and services. With the uncertainty of the implementation schedule, the practice of collusion and nepotism between procurement managers and prospective implementers is even greater, because those who know for sure the time of implementation only the procurement manager where the procurement can be decided immediately, even though the time is not on schedule, this is what open the opportunity to practice collusion and nepotism, because only prospective providers are automatically known companies that are contacted. The following excerpt of the interview concerns the suitability of the schedule for the procurement of goods and services with questions from the Author, namely in the procurement of goods and services to be held, whether in accordance with the schedule of procurement of goods and services compiled. The informant gave the following answer.

"For now I think almost every SKPD, there are those whose schedules are right there are those who do not, all of them return to the leadership, because to determine the procurement of goods and services will start depending on supervisor instructions, even though according to the schedule must be held, but not the leader's instructions, surely the procurement will not be held until there are instructions from the leadership "(PPK 1).

"For certain jobs such as the procurement of stationery or disposable items usually on schedule, there will also be procurement such as laptops and other office equipment sometimes not according to schedule (PPK 2).

"Procurement schedules usually follow a predetermined cash budget, but can change at any time as needed ... ....... (PPK 2).

Procurement officials in the regional apparatus who became informants gave similar answers to the informants who had the position of commitment-making officials. The following are the results of interviews with informants.

"There are those that are on schedule, but there are those that are sometimes not on schedule depending on the supervisor's instructions which are mostly not according to the schedule of physical works ......... (Procurement Officer 2).

"Not always, sometimes there are those that are in accordance with the cash budget, sometimes there must be a shift in the budget because it is faster than planned" (Procurement Meeting 4).

Sometimes, there are regional officials who see that the implementation schedule problems do not have a big impact on the management of procurement of goods and services in the regional apparatus, but in fact the schedule for the procurement of goods and services can be a big gap for procurement managers to practice collusion and nepotism. . With the failure to procure goods and services in the regional apparatus according to the schedule, especially procurement with a value below Rp. 200,000,000, sometimes information on changes is only known to the apparatus and service providers in the regional apparatus, so sometimes the information is only conveying to prospective providers who have closeness with them, so that when the procurement of goods and services is carried out, only the prospective provider is ready, so that they automatically become the winner of the procurement. 


\subsection{Discussions}

The results of this study clearly show that the APIP from the Inspectorate was quite maximal in carrying out the supervision of the application of the principle of competitiveness in the management of the procurement of goods and services in the North Sulawesi Provincial Government. However, the problems of regional officials who have not yet followed up will be suggestions for improvement from the Inspectorate. For prominent problems the application of the principle of competitiveness in the regional apparatus, namely: there are still interventions to the management apparatus for the procurement of goods and services in SKPD, the implementation of price negotiations is sometimes only done in formality, even when it is not done and uncertainty about the implementation schedule goods and services.

Intervention from holders of higher power to the apparatus is something that is still often found especially in the implementation of the procurement of goods and services at the SKPD. These interventions include determining the winner of the procurement of goods and services, intervening in the procurement of goods and services, intervening when examining work results and intervening in the process of payment for the procurement of goods and services. Interventions that are recognized most often by the management apparatus for the procurement of goods and services include the determination of the company that will be the winner. With such interventions, it will automatically have a lot of impact on the management of goods and services, there are companies that are actually very competent to compete to get work packages at SKPD, eventually not getting any packages, while there are companies that are actually less competent, often get jobs because there is an element of closeness with the SKPD leadership. The results of the study from Mulyono et al (2013) that there is still intervention in the process of procurement of goods and services. Intervention both politically and the implementation pressure from the company to get the project is still difficult to avoid.

Mokoginta (2017) gives an opinion regarding the intervention of managers of goods and services procurement at SKPD. The form of intervention that often occurs in the process of procurement of goods / services is the presence of orders or pressure to win certain providers. The term commonly used is "direction / deposit" which is wrapped in the word "policy". Interventions make KDP unable to do much even though they actually know something is wrong. The authority of the PPK seems to be castrated. PPK is not active in carrying out its duties and its authority controls the implementation of contracts. On the contrary, often providers or other parties control the implementation of contracts. The contract which ended with the handover of the work also did not escape the intervention. The handover report (BAST) of the work must be signed by PPHP even though the results are not in accordance with the provisions stipulated in the Contract.

\section{CONCLUSION}

\subsection{Conclusion}

On results of the study it was concluded that the Inspectorate was maximal enough in carrying out supervision of the application of the principle of competitiveness in the management of the procurement of goods and services in the North Sulawesi Provincial Government. However, regional authorities have not fully applied the principle of competing in the management of goods / services procurement to the government of North Sulawesi Province. This is due to problems such as the existence of interventions to the management apparatus for the procurement of goods and services in the SKPD, the implementation of price negotiations is sometimes only done in formality, even when it is not done and the uncertainty of the implementation schedule for the procurement of goods and services. 


\subsection{Suggestion}

On the results of this study, it is recommended that regional governments need to create a special team consisting of APIP and Regional Personnel Bodies, which later they will be tasked with consulting officials for procurement of goods and services in SKPD so that they can consult or pressure specifically with this team, which later this team will be the mediator for officials managing the procurement of goods and services at the SKPD both with the SKPD head and the implementing party. The regional government in this case the regional inspectorate needs to make education and training on a regular basis about the implementation of goods and services procurement in SKPD whose material is not only about the procurement of goods and services in SKPD but also adds material on the effects of the procurement of goods and services in SKPD, so knowledge from executing officials in the procurement of goods and services in SKPD can increase, not only regarding procurement but negative impacts if they make irregularities in the procurement of goods and services at SKPD.

\section{REFERENCES}

Anonimous, (2011a). Procurement Procedures Manual for Public Procurement In Nigeria. Bureau Of Public Procurement (BPP). Second Edition.

Arsana, I. P. J. (2016). Manajemen Pengadaan Barang dan Jasa Pemerintah. Jogjakarta: CV. Budi Utama.

Hardi, M. (2016). Resiko/Permasalahan Dalam Pengadaan Barang/Jasa. Workshop Reviu Penyerapan Anggaran dan Pengadaan Barang/Jasa. Jakarta: Kemenristekdikti.

Heryandi, A., Afrianto, I., dan Sufa'atin, (2011). Kajian Sistem Pengadaan Barang dan Jasa Menuju Arah E-Procurement UNIKOM Program Studi Teknik Informatika. Jurnal Fakultas Teknik Dan Ilmu Komputer Majalah Ilmiah UNIKOM Vol.10 No. 12011.

Irianto, S. (2014). Negosiasi dan Memorandum of Undestanding (MoU) dalam Penyusunan Kontrak. Jurnal Hukum dan Dinamika Masyarakat. Volume 12.

Listiyanto, A. (2012). Pembaharuan Regulasi Pengadaan Barang Dan Jasa Pemerintah (Reformation Regulation of Goods and Services Government Procurement). Jurnal Rechts Vinding. Media Pembinaan Hukum Nasional Issn 2089-9009. Volume 1 Nomor 1.

Lubis, A. S. (2014). Prinsip-Prinsip Pengadaan Barang/Jasa Apakah Harus Dipedomani? Jakarta: Badan Pendidikan dan Peltihan Keuangan Kementerian Keuangan.

Maribun, B. N. (2003). Kamus Manajemen. Jakarta: Pustaka Sinar Harapan.

Milles, M.B. and Huberman, M.A. (1984). Qualitative Data Analysis. London: Sage Publication.

Mokoginta. R. (2013). Terjepit Diantara Integritas dan Intervensi. Available at: https://rahfanmokoginta.wordpress.com/2013/09/02/terjepit-diantara-integritas-danintervensi/.

Mulyono E., Martoyo, Listiani E. I., (2013). Implementasi Pengadaan Barang Dan Jasa Pemerintah Berdasarkan Peraturan Presiden Nomor 54 Tahun 2010 (Studi Pada Dinas Pekerjaan Umum Kota Pontianak). Pontianak: Jurnal Tesis PMIS-UNTAN-PSIAN2013.

O'Regan, K. (2012). Stamping Out Corruption Is Everybody's Business. viewed 11 Desember 2016. Available at: http://www.corruptionwatch. org.za/content/stampingout-corruption-everybody\%E2\%80\%99s-business-0 
Rheza, (2011). Konsep Pengawasan Manajemen Ekonomi. http://rhezamain.blogspot.com/2011/06/konsep-pengawasan-manajemen-ekonomi.html. Search: 15 April 2018.

Salim, P. dan Y. Salim. (2002). Kamus Bahasa Indonesia Kontemporer. Jakarta: Modern English Press.

Saroinsong D., Panelewen, V. V. J, Laoh, O. E. H., dan Pakasi C. B. D., 2012. Agribisnis Tanaman Stroberi Di Desa Rurukan Kecamatan Tomohon Timur. Eugenia Volume 18 No. 3 Desember 2012.

Sugiyono. (2008). Metode Penelitian Bisnis. Alfabeta : Bandung.

Tanesia, R. K. (2015). Studi Efektifitas Pengadaan Barang Dan Jasa Pemerintah Secara Tradisional Dan Elektronik. Jurnal Teknis Sipil Volume 13, No. 2, April 2015.

Willem, S. (2012). Manajemen Pengadaan, Procurement Management. Bandung: Alfabeta.

World Heritage Encyclopedia, 2008. List of Indonesian provinces by Human Development Index.

http://www.gutenberg.us/article/WHEBN0028699244/List\%20of\%20Indonesian\%20pr ovinces\%20by\%20Human\%20Development\%20Index.

Yulika, A (2015). Peran Inspektorat Dalam Mengawal Pengadaan Barang Dan Jasa. https://slideplayer.info/slide/11947467/. Search: 15 April 2018. 